\title{
11 BLOWN TO WITEWITEKALK: PLACENAMES AND CULTURAL LANDSCAPES IN NORTH-WEST VICTORIA
}

\author{
Edward Ryan
}

Indigenous placenames of north-west Victoria originate in what has been described as the western Kulin group of languages which were traditionally spoken across the region.' More particularly in terms of this paper, Wergaia speakers occupied the northern Wimmera and much of the Mallee and were bounded on the north-east from around Lalbert Creek by speakers of Wemba Wemba. Current knowledge of the placenames of this area is limited by problems common to other areas of 'settled' Australia, involving a lack of knowledge of the dynamics of European naming processes, in addition to ignorance of that of the original inhabitants. As relevant surveyors' field notes do not appear to have survived, there are no data extant on the language affiliation of the 'native guides' necessary for early cartographic expeditions, and very little information on other indigenous sources for early placename compilations. Later problems experienced elsewhere across settled Australia, such as the migration of placenames, particularly during the creation of parish-based land divisions, have made the situation even more confusing.

An example from the region of such migration is seen in the case of the placename Carapugna, currently found between the towns of Birchip and Nullawil. In the division of the area into a parish system in the late nineteenth century, Carapugna moved 35 kilometres east of its earliest recorded position and changed from being the name of an outstation on the Morton Plains pastoral run, to being the name of a newly created parish. During the same period, Whirily became a parish placename located well to the north of its original location referring to a waterhole on the Wirrimbirchip pastoral run. More unusually, it appears to have metamorphosed into a form involving the Irish surname O'Reilly for a time, before resuming a supposedly indigenous form with the creation of parishes. The meaning of these placenames and indeed many others in the area remains opaque, despite the identification of original locations.

\footnotetext{
Hercus (1986).
}

L. Hercus, F. Hodges and J. Simpson, eds, The Land is a Map: placenames of Indigenous origin in Australia, 157-163. Canberra: Pandanus Books in association with Pacific Linguistics, 2002. 
A contributing factor to this lack of transparency is the absence of glosses accompanying maps. One gloss at least is extant, though, relating to a map of the area around the Tyrell and Lalbert Creeks and gives us further insight into the problems and potentialities involved in the use of cartographic material. Among the placenames listed is Cooroopajerup with 'news of water' given as a translation. No relevant data appear to exist in either the nineteenth century linguistic compilations or the work of Luise Hercus to translate this but the morpheme jerup is a recurring one in local placenames and is always found in relation to water. Besides the lake on the map in question, a Cherrup Swamp is recorded near Charlton, and a Cooroopajerup and Tcharrup Tcharrup Creek - both ephemeral and known only from oral sources - run from the Charlton area north to join the Tyrell Creek. White Jagur Swamp also appears on the map and is glossed as 'wattle blossom'. The Wergaia word for golden wattle, wadj, may be a relevant translation in the case of 'White'. This form is also found applied to a clan further west in Wergaia country, termed the 'White Cundie Bulluk', and may well refer to the ecology of the clan's territory. ${ }^{2}$ The form Jagor is given in nineteenth-century sources as a word for swamp and thus a more direct translation could be 'wattle swamp' rather than wattle blossom. Another example from the list is 'Lar Mitiyen', glossed as 'moon camp', which in distinction to the cases above is a direct and accurate translation. The question remains though - what does a 'moon camp' mean? Even when names are linguistically transparent they can remain opaque in cultural terms. A final example here is 'Brimybill' which appears to be a transcription of 'Brambimbul', the name of the two brothers Bram, the central ancestral figures in the creation of much of the landscape of western Victoria. This is confirmed by the gloss of 'brothers lake'. There is something to be gained then from a more rigorous analysis of such sources despite their apparent shortcomings; but there is also the danger that such an examination when undertaken in the absence of greater knowledge of traditional society could result in the compilation of sterile word lists largely devoid of indigenous cultural meaning. Fortunately there is material in the ethnographic record which provides some semblance at least of indigenous conceptions of place.

Woodford Robinson, 'a native of the Loddon' whose language was Wemba Wemba, provided a clear statement of the origin of placenames in a story he told the Reverend John Mathew in $1909 .{ }^{3}$ The story concerned is a Brambimbul narrative and relates an account of how the Brambimbul killed the spiders Werimbul and their dogs and then points out the location of the Brambimul in the sky. They are the two pointers of the Southern Cross and are standing near the donggal, which is the big black hole beneath the Southern Cross. This donggal, black hole, comprises two bunyips which the Brambimul killed near Koondrook at Gannawara on the Gunbower Creek, where there is a basin with deep water. After the Brambimbul killed the two bunyips, they cut them up to feed the people and the different peoples ate different parts of the bunyips. Some ate the flesh, some the fat and some even the mud that was on them and this caused the difference between the languages of the various tribes. We have contained in one story an account of how the Brambimbul shaped the landscape and its equivalent in the sky and created the different languages of the region through their actions. Thus the constituents of placenames, language, country and cultural practice are clearly derived from and linked to the Brambimbul. The importance of the ethnographic record as a means of deepening our understanding of traditional conceptions of place is also demonstrated.

\footnotetext{
2 See Clark (1990:360).

3 J. Mathew, MS 950, Australian Institute of Aboriginal and Torres Strait Islander Studies, Canberra.
} 
It can be difficult to use such ethnographic material though because of the lack of attention by early ethnographers paid to the identities of the Aboriginal people involved. A.W. Howitt referred to his main informant for what he termed the Wotjoballuk tribe as 'Bobby', a name common to a number of men across the region at the time under nineteenth-century European naming practices. ${ }^{4}$ Bobby can be identified, however, by association with other Aboriginal people and by association with country he describes in his stories. Specifically he narrates a tale of how, after transgressions by the tribe, the ancestor figure Kurn burned down the giant pine tree that linked the ancestors of the Richardson River people to the sky. When the tree fell some people were left in the sky and the depression, now known as Lake Buloke, was formed at Banyenong. The kernels of the pine tree fell out across the country to become the stones that lie across Morton Plains to Lake Tyrell. While the same elements of location in the sky and on the earth and the actions of ancestor figures shown in Woodford Robinson's story are again present, we can also deduce that the 'Bobby' narrating is the historical figure Morton Plains Bobby or King Robert. He was the second-last traditional head of the Bulugdja (or lake) clan of the Wergaia people whose country included those locations mentioned in the story. A clear picture of places of importance in Bobby's country can be seen on the map of the Morton Plains pastoral run, c.1850 (see Figure 1). ${ }^{5}$

While the story of Kurn and the ancestors of the Richardson River people explains the nature of local country, the Bram brothers' story cycle explains country right across the territory of Wergaia and other related peoples. In one of the main narratives from the cycle narrated by Bobby a range of places from the Lower Wimmera River in the south to Pine Plains in the north are mentioned. The location of some of the events of the narrative are given with their European equivalents and so the way the landscape was formed becomes obvious but at other times this is not the case. After a series of adventures with other beings the Brambimbul enter a contest with Gertuk the tree creeper during which Gertuk unleashes his bag of whirlwinds and the Bram brothers have to cling to trees for support. The elder brother held a strong pine and was safe but the younger held a small tree and was blown a great distance to 'Witewitekalk'. Witewitekalk translates as 'small tree' of which there are many in the Mallee and were many more in the 1880s when Howitt interviewed Bobby and when read out of cultural context this placename would remain an obscure piece of cartographic data. Turning to the map of Bobby's home country of Morton Plains though we can move beyond this as we find the placename Witchagulk - a cognate of Witewitekalk and presumably the place mentioned in the narrative given the highlighting of the normally inconsequential 'small tree' in both story and placename.

4 A.W. Howitt, MS 759, National Museum of Victoria.

5 Illustration and other cartographic information from Historical Maps Collection, Department of Natural Resources and Environment, Victoria. 


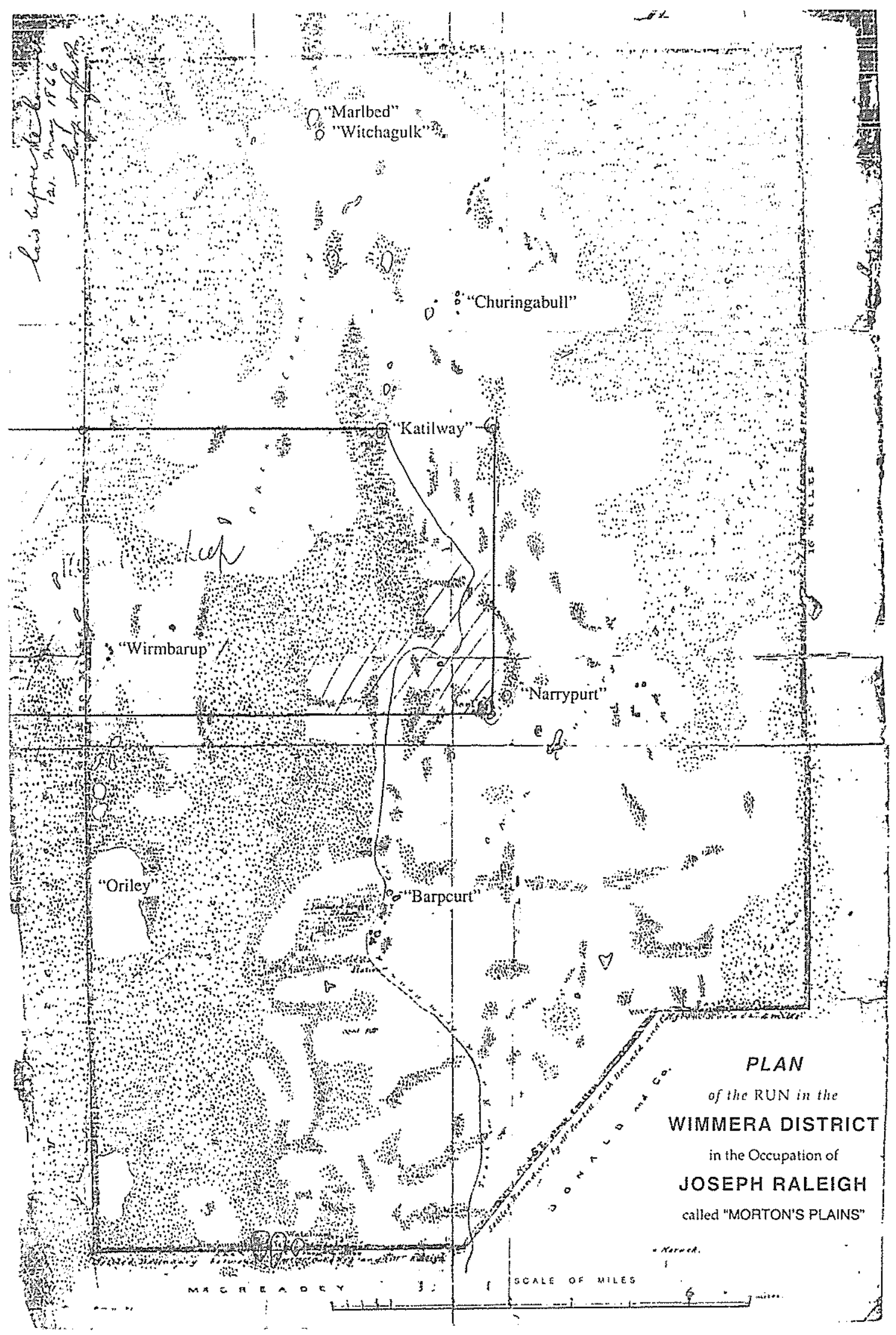

Figure 1: Map of the Morton Plains pastoral run, c. 1850 
Narrative cycles are naturally not the only basis for placenames in the area, as exemplified by Watchem on the southern boundary of the Morton Plains pastoral run. This name is generally translated as 'silver wattle' which may be an accurate rendering given the presence of the morpheme wadj, meaning 'golden wattle' as noted above. King Anthony Anderson, last traditional head of the Bulugdja clan, stated to European settlers that this was the case and strong stands of wattle originally grew near the lake at Watchem. An alternative origin of the name was given by 'Syntax'. 'Blackfella lie alonga lake to watchem wild cattle come for water; then blackfella spear cattle'. 'While this story gives us a good insight into the use of humour and irony by Aboriginal people when questioned on country by Europeans, it also illustrates the importance of the lake to its traditional owners and incoming settlers as one of few sources of permanent water in the area. However, not all placenames in the area refer to water sources. A range of documentary sources refer to a King Barney of Brabcut but in doing so illustrate a mis-hearing of Indigenous words and a misunderstanding of traditional authority systems. Brabcut is more accurately rendered barpcurt in the earliest sources including the 1850 pastoral map of Morton Plains. The initial morpheme of the name is transparent in meaning and represents burb - the Wergaia word for head or hill, which is also found in the nearby placename Wycheproof - widji burb meaning 'basket grass hill'. Barpcurt was the site of the Morton Plains head station, which occupied a rise in a generally flat area. In terms of a mis-reading of traditional authority systems King Barney of Brabcut was in fact a Djadjawurrung man from near St Arnaud but was free to much of Wergaia country because his mother came from Pine Plains and he spent much time on Morton Plains, the country of his wife Maria of the Bulugdja clan of the Wergaia. Rather than being a traditional head man of the Wergaia, his authority among Aboriginal people of the area came from him being a bangal, that is a 'Doctor' or 'Clever Man'.

Another individual named Syntax was also titled King of Brabcut, possibly again through being a bangal. Regardless of his place in the traditional authority system, his relation to place warrants further scrutiny. There is little evidence of King Syntax, otherwise known as Godfrey Syntax, leaving his immediate clan territory, unlike many other clan members. Following the relocation of the last of the old people of the clan including Morton Plains Bobby to the Ebenezer Mission on the Wimmera River in 1884, King Syntax appears to have lived as the sole permanent traditional inhabitant of the area until his death aged 50 in December 1885 . In an area rapidly being taken up for closer settlement by incoming selectors he chose to live in his camp at Lake Marlbed. While this was still part of a pastoral run and so was less environmentally changed, it was at the northern end of the Bulugdja traditional country and well away from permanent reliable water sources to the south such as those at Watchem and Lake Buloke. As this site was of great inconvenience in utilitarian terms, its significance as a location for him then must be sought in the cultural realm. Lake Marlbed home station, as can be seen from the map, is also the location of Witchagulk, the site where the younger of the two Bram brothers was blown by Gertuk's whirlwinds in Bobby's Brambimbul narrative.

\footnotetext{
6 Either Syntax Harrison or Godfrey Syntax.

7 Donald History and Natural History Group (1989:41).
} 


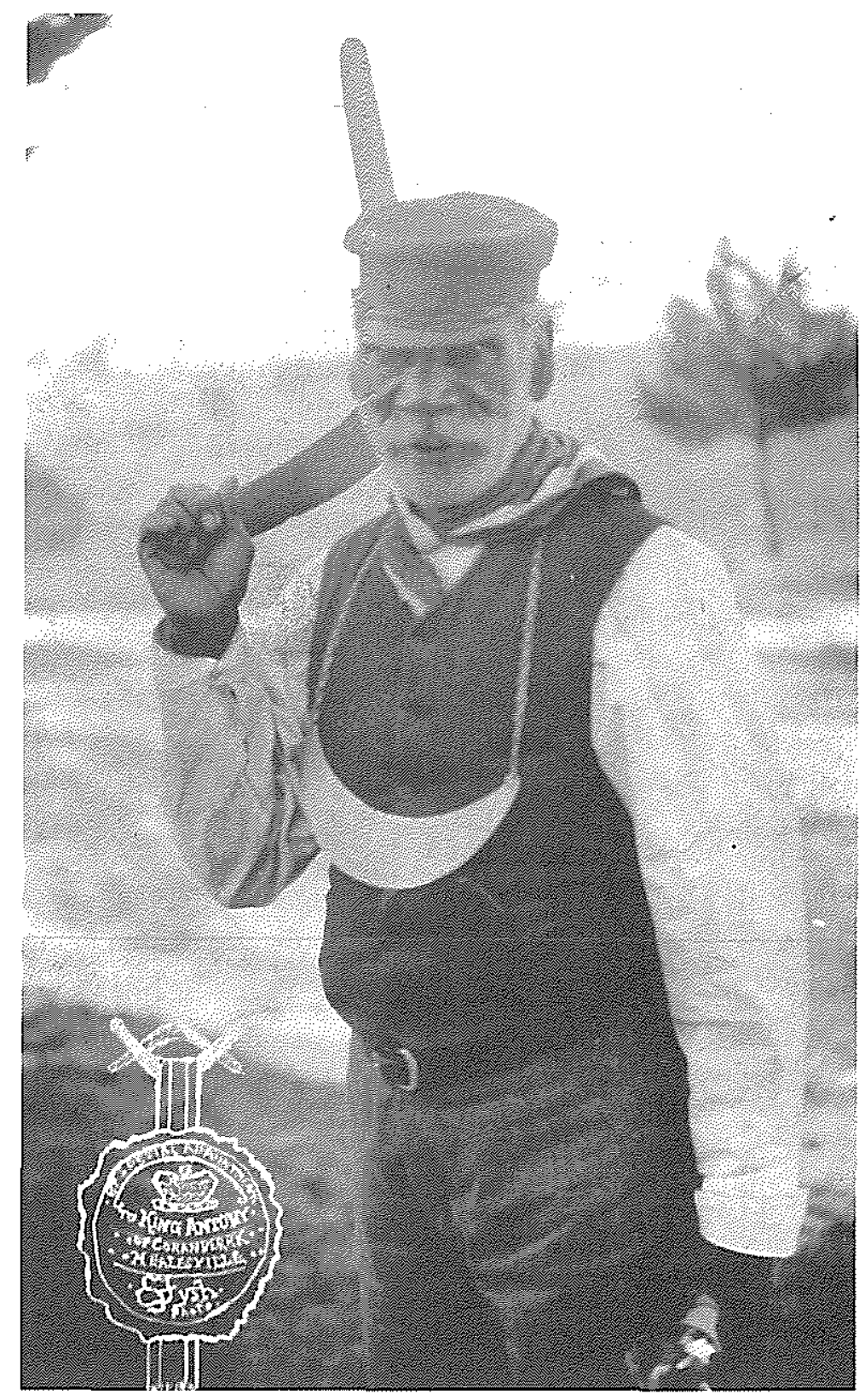

Figure 2: King Anthony Anderson, photograph courtesy of the State Library of Victoria.

Evidence exists of a similar choice being made by King Anthony Anderson. After travelling over Wergaia and other country to which he was 'free' and well beyond for some years, King Anthony settled back on his clan country as he grew older in the 1890s. Though drawing Protection Board rations from the new township of Birchip, he too chose to camp in drier country well to the north at points such as Gould's Lagoon and Marlbed, each 15 kilometres from town. Ethnographic sources again contain material which may help explain this 'illogical' choice through shedding more light on the place of Witchagulk in Bobby's Bram brothers narrative. Sergeant Major, a son of King Barney who had also spent much time in Bulugdja country, explained to A.W. Howitt that the Bram brothers were of the Patjingal or pelican moiety subsection. While Patjingal was a subsection name common to both white cockatoo and black cockatoo moieties, Sergeant Major also stated that the mother of the Bram 
brothers, Tuk the bullfrog, was of the black cockatoo moiety. ${ }^{8}$ Working on the basis of matrilineal descent of moiety affiliation, the Bram brothers must then have been black cockatoo men - as indeed was King Anthony Anderson.

There is an evident need to consider the narrative cycles associated with the ancestral beings and indeed a range of other cultural and historical material when considering Indigenous placenames in settled south-eastern Australia. In some ways this may be of even more importance than in areas where language and traditional culture are stronger as there are less linguistic data available to attempt to bring some degree of transparency to placenames. As can be seen in the case of north-west Victoria, a discussion based on wider cultural considerations can not only contribute to the attempted translation of opaque placenames, but also provide transparency to the actions of known historical figures to whom those placenames had associations of great importance.

In adding cultural knowledge to what we know of the lives of the people of the north-west, and in comparing the actions of the ancestor beings with the actions of the Wergaia and associated peoples, we can begin to approach an understanding of the deeper meanings of the Indigenous placenames of the region. In doing so, we can retrieve placenames from the obscurity of antiquarian maps and begin to place them in the cultural landscapes in which they belong. We can move beyond Indigenous placenames taking the role of collectables without context as mere names on a page and indeed move beyond Witewitekalk.

\section{REFERENCES}

Clark, I.D., 1990, Aboriginal Languages and Clans: an historical atlas of western and central Victoria, 1800-1900. Clayton: Monash Publications in Geography.

Donald History and Natural History Group, 1989, Past \& Present: 'The Donald Times' jubilee souvenir. Donald.

Hercus, L.A., 1986, Victorian Languages: a late survey. Canberra: Pacific Linguistics.

Historical Maps Collection, Department of Natural Resources and Environment, Victoria.

Howitt, A.W., MS 759, National Museum of Victoria.

- MS 9356, La Trobe Library, State Library of Victoria.

Mathew, J., MS 950, Australian Institute of Aboriginal and Torres Strait Islander Studies, Canberra. 